\title{
Model Technology to Performance Chain (TPC) in Implementing Accrual-Based Sistem Informasi Manajemen Daerah (SIMDA) Finance: Empirical Evidence from Local Government of Indonesia
}

\author{
Willy Abdillah $^{1}$, Asep Saepullah ${ }^{2}$ \\ Faculty of Economics and Business, Bengkulu University, Bengkulu, Indonesia
}

\section{Info Article}

\section{History Article:}

Received February 2018

Approved February 2018

Published March 2018

\section{Keywords:}

Job Characteristics; Technology

Characteristics; Task-Technology

Fit; Utilization; Performance

Impact; Local Government.

\begin{abstract}
This study examines TPC model in the context of utilization of accrual-based SIMDA Finance version 2.7 at Local Government of Indonesia. The success of SIMDA Finance development is not only determined by how the SIMDA Finance can process quality information, but also determined by its suitability to the work environment and its user duties. This study uses 2.056 of financial administrators of Local Government Department, consisting treasury admission, spending treasury, and operator. Online questionnaire distributed by snowball sampling with 24.5 percent of response rate and examined by Partial Least Square (PLS) technique. This study found that Job Characteristics and Techology Characteristics effect on Task-Techology Fit (TTF), Utilization, and Performance Impact. Theoretically, the study found that the TPC model was able to explain the context of public sector organizations, especially government agencies in Indonesia, outside of the organizational context when the TPC model was developed and developed earlier. Practically, the implications of research findings for stakeholders of SIMDA Keuangan are discussed further.
\end{abstract}

\section{Model Technology to Performance Chain (TPC) pada Penerapan Sistem Informasi Manajemen Daerah (SIMDA) Keuangan: Studi Empiris pada Pemerintah Daerah di Indonesia}

\begin{abstract}
Abstrak
Penelitian ini menguji penerapan model TPC pada Sistem Informasi Manajemen Keuangan Daerah (SIMDA) versi 2.7 di lingkungan pemerintahan daerah di Indonesia. Keberhasilan dari pengembangan SIMDA Keuangan tidak hanya ditentukan oleh bagaimana SIMDA Keuangan mampu memproses kualitas informasi, tetapi juga ditentukan oleh kesesuaian lingkungan kerja. Penelitian ini menggunakan sampel sebanyak 2.056 yang terdiri dari administrasi keuangan di tingkat pemerintahan daerah, diantaranya adalah bendahara daerah dan operatornya. Kuesioner disebarkan secara daring menggunakan model sampel snowballing dengan tingkat respon 24,5\% serta data kemudian diuji menggunakan Partial Least Square (PLS). Penelitian ini menemukan bahwa karakteristik pekerjaan dan karakteristik teknologi mempengaruhi task-technology fit (TTF), utilisasi dan dampak kinerja. Secara teoritis, pengujian ini menemukan kesimpulan bahwa model TPC dapat diaplikasikan pada sektor institusi publik terutama organisasi pemerintahan. Dampak dari penerapan SIMDA terhadap pemangku kepentingan yang lain akan menjadi bahan pengujian selanjutnya.
\end{abstract}

JEL Classification: G3, G38 


\section{INTRODUCTION}

Based on Government Regulation of the Republic of Indonesia No. As amended by Government Regulation No. 65 of 2010 on Information System (SI) of Regional Finance, local governments are obliged to develop and utilize the progress of IT to improve local financial management capabilities, and to distribute regional financial information to the public. One form of IT utilization is the use of software as a tool in the accounting and financial systems of the region. Therefore, a good financial management system is required in order to manage local finances accurately, on time, transparently and accountably.

In line with the implementation of IS accounting at local government, Badan Pengawas Keuangan dan Pembangunan (BPKP) gave a positive response by providing a computer application program called Sistem Informasi Manajemen Daerah (SIMDA) which was introduced on August 29, 2006 and new version 2.7 to comply with PP No. 71 of 2010 on Government Accounting Standard (SAP) which is a substitute of PP No. 24 of 2005 and Regulation of the Minister of Home Affairs Number 64 Year 2013 on the Implementation of Accrual Based Government Accounting Standards At Local Government. However, several problems found while using the application due to features complexity and lack of training and socialization. System changes that often occur have direct impact on the user's attitudes. Users are required to quickly adapt to the new system especially to a mandatory system because the user has no choice to accept or reject the adoption of the new system.

The success of SIMDA Finance development is not only determined by how the SIMDA Finance can process quality information, but also determined by its suitability to the work environment and its user duties. Because, although SIMDA Finance is technically sophisticated, SIMDA Finance development can not be said to succeed if SIMDA Finance users are resistent to accept it, or if the SIMDA Finance can not improve the performance of the wearer even degrade employee morale. This phenomenon is interesting to investigate several factors in the implementation of SIMDA Finance version 2.7 which can affect the improvement of individual performance. In addition, lower level of SIMDA usage is feared to be the main cause of productivity paradox, which is expensive investment in the system field but produces low returns (Davis \& Venkatesh, 2000). Therefore, it is necessary to review the acceptance and impact of SIMDA on the performance of local government in Indonesia.

IS acceptance and utilization issues can be measured by some SI adoption and utilization models, such as End-User Computing Satisfaction (EUSC), Task Technology Fit (TTF), Technology to Performance Chain (TPC), Human-Organization-Technology (HOT) Fit Model, and Technology Acceptance Model (TAM). The TPC model is a relevant model measuring the performance impact of SI reception and utilization (Goodhue \& Thompson, 1995; Asrori, 2011; Parkes, 2013; Aljukhadar et al., 2014).

Goodhue and Thompson (1995) initiated the development of the TPC model by proposing the concept of Task Technology Fit (TTF) to guide individuals to achieve better performance. This theory assumes that IT has a positive impact on individual performance and can be used if the IT capabilities match the tasks that will be done by the user. Due to the limitations of this model, Goodhue and Thompson (1995) propose a model that combines utilization with the TTF model, the TPC model. The TPC model explains that technology should be utilized and appropriate to the tasks that support users in order to achieve performance impact. The TPC model provides a more accurate picture of technology, user tasks, and utilization relationships with performance changes. Therefore, the TPC model is the relevant model used to assess the acceptability and performance impacts of SIMDA use in local government environments in Indonesia.

This research is important because the implementation of SIMDA Finance has been 
widely used in local government environment in Indonesia and used for public service in Indonesia. In addition, research on the factors that influence the implementation of SIMDA Finance in government institutions in Indonesia is still relatively limited. Thus, this research is expected to provide practical information for local government agencies in Indonesia on the impact of SIMDA Finance implementation and its impact on performance. Theoretically, this research is expected to develop TPC model testing in public sector environment, especially government institution.

\section{Hypothesis Development}

The user of the system is a human who psychologically has certain behaviors attached to him, so that the aspects of keprilakuan in the human context as the user of IT becomes important as a determining factor on everyone who uses IT. According to Lin and Huang (2008), these behavioral considerations need to be given special attention in the context of IT implementation. This opinion is in line with Baroudi et al. (1986) stating that technical factors, behaviors, situations and user IT personnel need to be considered before IT is implemented. Hartwick and Barki (1994) also suggested that the user behavior aspect needs to be considered in system development, which is related to the user's understanding and perspective on the system. Thus it can be concluded that the perception of the personnel involved in the implementation of the system will affect the success or failure of a system, accepted or not, useful or not the system when applied.

The technology to performance chain (TPC) model is a comprehensive model constructed from two complementary research groups: user attitude as a predictor of the utilization and suitability of technology tasks tasktechnology fit) as a predictor of performance. The essence of this model is that IT has a positive impact on individual performance so the technology must be utilized and must be in accordance with the type of work done (Jogiyanto, 2007).
Furthermore, Jogiyanto (2007) explains that the technology to performance chain (TPC) model is a model that measures the performance impacts of IT use by individuals. Recognizing that technology should be utilized first and fit with the tasks supported by its technology for performance impact, this model provides a more accurate picture of how technology, user tasks, and utilization are related to achieve performance. In the TPC concept, the effect or reciprocal effect of a good performance outcome is a reflection of the successful implementation or implementation of the SI. So it can be simply described that the performance of individual users of the SI reflects the success rate of implementation of the system being run.

According to Susanti (2006), TPC is an assertion for IT that has a positive influence on individual performance, technology must be utilized and technology must be fit with supported tasks. In simple terms the TPC model that has been tested by Goodhue and Thompson (1995) is a Task Technology Fit model with the addition of variable utilization.

Oliveira et al. (2014) mentioned that TPC is a measure of a technology assisting individuals in the performance of their duties or tasks of office. More specifically, Technologi to Performance Chain is an adjustment between the need for tasks, individual abilities and technological functions. Priority Technologies to Performance Chain is the interaction between task, technology, and individual. A variety of tasks that definitely require a wide range of definite technological functions. This model indicates that performance will increase when a technology provides the right features and support associated with the task.

Montazemi et al. (1996) explain that TPC model is a model of technology performance chain where IT is an activity chain that improves individual and organizational performance. The fundamental difference of the TTF model with the TPC model is the inclusion of the utilization variables in the TPC model, whereas in the TTF model the utilization variables are not included with the consideration if the use of 


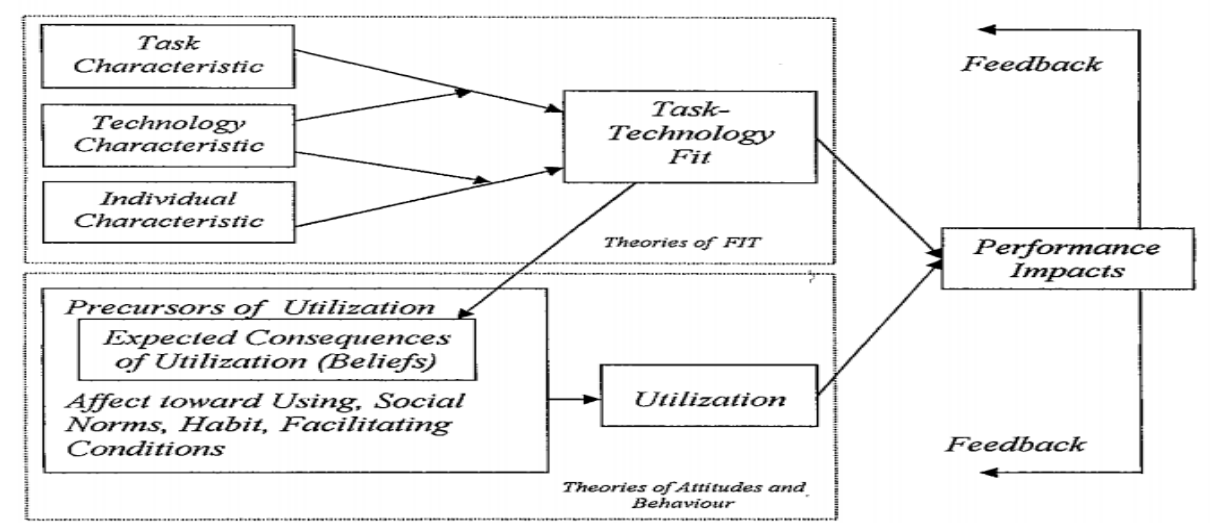

Figure 1. TPC Model, Goodhue dan Thompson (1995)

TTF is an option or necessity, then the utilization variable may not be included as a variable to measure performance. In the TPC model, the utilization variable is still an optional one, whereby full system utilization is the choice for the user. Figure 1 presents the TPC Model.

This research uses TPC model approach which has been tested by Goodhue and Thompson (1995) which aims to measure the effect of SIMDA Finance 2.7 implementation on the performance of its users through the measurement of the variables in the model used.

\section{Effect of Job Characteristics on TTF}

Characteristic of task is activity done by individual in converting input to output. Previous research with the TTF model has found that task characteristics affect task-technology conformance (Goodhue \& Thompson, 1995; Zhou et al., 2010; Oliveira et al., 2014; Lu \& Yang, 2014). A person who is often involved in routine tasks in his work will make certain judgments when faced with the use of new IT that requires conformity of tech tasks (D'Ambra et al., 2013).

This study argues that the better the characteristics of the tasks implemented in the implementation of SIMDA Finance version 2.7 then the level of compliance task technology application SIMDA Financial version 2.7 will be better. Thus, the proposed hypothesis is as follows:

$\mathrm{H} 1$ : Job characteristics has positive effects on TTF.

\section{Effect of Technology Characteristics on TTF}

The characteristics of technology are the tools (hardware, software, and data) used by individuals in helping to accomplish tasks (Goodhue \& Thompson, 1995; D’Ambra \& Wilson, 2004). Previous studies have found that technological characteristics influence the suitability of technological tasks (D'Ambra et al., 2013; Yadegaridehkordi et al., 2014; Lu \& Yang, 2014).

In an organization, technological characteristics are the basis for evaluating the use of IT in the user's assessment of the degree of conformity of everyday technology tasks. the suitability of tech tasks is a rational perspective as to whether the technology used can optimize user tasks (Oliveira et al., 2014). It is increasingly asserted that the suitability of tech tasks is influenced by the task characteristics and practicality of the technology used in assisting the work or task of the everyday user.

This study argues that the better the characteristics of technology used in the application SIMDA Finance version 2.7 then the level of compliance task technology SIMDA Financial version 2.7 will increase. Thus, the proposed hypothesis is as follows:

$\mathrm{H} 2$ : Technology characteristics has positive effect on TTF.

\section{Effect of TTF on Utilization}

Goodhue and Thompson (1995) argue that the suitability of technological tasks influences IT utilization. Previous studies have also found that the suitability of tech tasks in- 
fluences the use of IT (Larsen et al., 2009). The conformity of technological tasks is a decisive factor of belief about the usefulness, importance of use, and benefits derived from the use of IT (D’Ambra et al., 2013).

Sophisticated technology can not always improve productivity and IT must have conformity in helping individuals complete their tasks (Lin \& Huang, 2008; Zhou et al., 2010). In other words, although the technology can be considered as advanced or sophisticated, but if it does not fit the requirements of the user's tasks they are unlikely to use it. McGill and Klobas (2009), found a positive relationship between TTF and utilization of information technology. This suggests that individuals will increase the use of information technology if the information technology is applied according to their task.

This study argues that the higher the suitability level of the application of the application technology of SIMDA Finance version 2.7 which is applied, will further improve system utilization. Thus, the proposed hypothesis is as follows:

H3: TTF has positive effects on utilization.

\section{Effect of TTF on Performance Impact}

The performance impact in this TPC model refers to the impact of IT deployment on individual user performance as measured by the variables present in the TPC model. The individual performance in question is the achievement of a series of individual tasks with existing IT support (Goodhue \& Thompson, 1995).

TTF is an ideal profile formed from a set of task dependencies that are internally consistent with the elements of technology used that will result in performance of task implementation (Jogiyanto, 2007). Technology according to the user in accordance with the demands that exist in the task and ability itself will lead to hope in the form of value or benefit value which will further encourage the user to utilize the technology.

Goodhue and Thompson (1995) used the TTF model and use as a predictor of the impact of individual performance in using IT. The results show data quality, timeliness, and relationships with SI predict the perceived positive performance impact. This model is consistent with DeLone and McLean (2003) who examine the use and attitudes toward technologies that affect the impact of individual performance. Several related studies also demonstrate the suitability of tech tasks affecting the impact of individual performance in using IT (McGill \& Klobas, 2009; D’Ambra et al., 2013). The suitability of tech tasks will affect individual performance if the functionality of IT available in the organization is capable of supporting daily user tasks.

This research argues that the more SIMDA Finance applications applied in helping the tasks of users so the performance of SIMDA Finance users will increase. Thus, the proposed hypothesis is as follows:

H4: TTF has positive effects on performance impact.

\section{Effect of Utilization on Performance Impact}

Research on SI utilization is generally based on user attitude and belief theory to predict IT utilization. Previous studies have found a positive between utilization and performance impact at the individual level in using IT (McGill \& Klobas, 2009; D’Ambra et al., 2013). This relationship is further strengthened by the later Delone and McLean (2003) research which identifies the SI success model as an antecedent to the performance impact that emphasizes the relationship between the use of SI by individuals on the impact of organizational performance.

In their research, Igbaria and Tan (1997) states that individual performance is a function of user use and satisfaction that aims to show how IT improves performance. The implication is the increase of IT utilization in this case SIMDA Finance version 2.7 will cause positive impact to the performance impact of SIMDA user. This study argued that the higher the utilization rate or application of SIMDA Finance version 2.7 then it can improve the user performance of SIMDA financial application 2.7. Thus, the pro- 
posed hypothesis is as follows:

H5: Utilization has positive effect on performance impact.

\section{METHOD}

This study examines the TPC Model in the context of Implementation of SIMDA Finance Version 2.7 within the Local Government in Indonesia. This research is quantitative type, that is explaining the relation of causality through hypothesis testing. The research design used was survey with questionnaire as instrument of data collection.

The latent constructs tested in this study are Task Characteristics, Technology Characteristics, Task-Technology Suitability, Utilization, and Performance Impact. The entire construct is measured using a 5 Likert scale from strongly disagree to strongly agree.

The study population is all financial managers who use SIMDA Finance in all work units of Local Government in Indonesia, consisting of SKPD Admission Admitters, SKPD Adjunct Receiving Treasurer, SKPD Spending Treasurer, and staff who are assigned to become SIMDA Operator in SKPKD. The total population unit is 2,056 people.

The type of data used is primary data and data collection methods using an online questionnaire distributed by snowball sampling. During the three months of data collection, i.e September-November 2017, a total of 504 returned questionnaires were eligible to be processed or response rates of 24.5 percent. All data were tested using the Partial Least Square (PLS) method with the help of SmartPLS version 2.0 M3. The testing phase consists of evaluation of measurement model for the test of construct validity and reliability, and evaluation of structural model for hypothesis testing.

\section{RESULT AND DISCUSSION}

\section{Respondent Characteristics}

In this study the respondent is the Regional Finance Manager who uses SIMDA Finance in his regular duties consisting of Expenditure Treasurer, Treasurer Acceptance, and Treasurer Acceptance of helpers and administrators and operators SIMDA who has filled out, return the questionnaire and complete the complete data. Characteristics of respondents in this study are described by sex, age, last education, accounting and non-accounting education base, working experience as a user SIMDA, knowledge of IT, and SIMDA training. Characteristics of respondents in this study can be seen in Table 1 below.

Table 1. Respondent Characteristics

\begin{tabular}{|c|c|c|}
\hline No & Categories & Percentage (\%) \\
\hline \multirow[t]{4}{*}{1} & Sex & \\
\hline & Male & 52.38 \\
\hline & Female & 47.62 \\
\hline & & 100 \\
\hline \multirow[t]{5}{*}{2} & Age & \\
\hline & 20-30 years & 7.94 \\
\hline & $31-40$ years & 66.67 \\
\hline & 41-50 years & 25.40 \\
\hline & & 100 \\
\hline \multirow[t]{6}{*}{3} & Education & \\
\hline & S2; & 6.35 \\
\hline & $\mathrm{S} 1$; & 61.90 \\
\hline & D3; & 11.11 \\
\hline & High school & 20.63 \\
\hline & & 100 \\
\hline \multirow[t]{4}{*}{4} & Qualification & \\
\hline & Accounting & 17.46 \\
\hline & Non-accounting & 82.54 \\
\hline & & 100 \\
\hline \multirow[t]{5}{*}{5} & Work experiences in & \\
\hline & SIMDA & 0 \\
\hline & $<1$ year & 100 \\
\hline & $>1$ year & \\
\hline & & 100 \\
\hline \multirow[t]{4}{*}{6} & IT knowledge & \\
\hline & IT knowledge & 100 \\
\hline & Non-IT knowledge & 0 \\
\hline & & 100 \\
\hline \multirow[t]{4}{*}{7} & SIMDA training & \\
\hline & Training & 77.78 \\
\hline & Non-training & 22.22 \\
\hline & & 100 \\
\hline
\end{tabular}


Tabel 2. Measurement Model Results

\begin{tabular}{lllllll}
\hline Var & AVE & $\begin{array}{l}\text { Composite } \\
\text { Reliability }\end{array}$ & RSquare & $\begin{array}{l}\text { Cronbachs } \\
\text { Alpha }\end{array}$ & Communality & Redundancy \\
\hline Perf & 0.657595 & 0.919500 & 0.275941 & 0.894717 & 0.657595 & 0.085826 \\
TC & 0.600251 & 0.912640 & & 0.889091 & 0.600251 & \\
TEC & 0.501171 & 0.921559 & & 0.910178 & 0.501171 & \\
TTF & 0.536494 & 0.958375 & 0.205608 & 0.955086 & 0.536494 & 0.031742 \\
UT & 0.928426 & 0.974941 & 0.242688 & 0.961409 & 0.928426 & 0.224628 \\
\hline
\end{tabular}

Respondent characteristics shows that equal opportunity for gender issue, productive ages, sufficient education, familiarity of system usage regarding user experiences, and basic knowledge and skills in the use of SIMDA Finance applications due to IT knowledge and SIMDA training.

\section{Measurement Model Results}

Measurement model is used to test construct validity (convergent and discriminant) and reliability (cronbach's alpha and composite reliability) of the research instrument. The parameters of the measurement model are obtained through the algorithm iteration process.

Convergent validity is related to the principle that gauges of a construct should be highly correlated (Ghozali, 2008). The Convergent validity reflective indicator test with the SmartPLS program can be assessed by looking at the output outer loading and Average Variance Extracted (AVE) results. For Smart PLS software, the rule of thumb used is outer loading $>0.70$ and Average Variance Extracted (AVE) $>0.50$, (Abdillah and Jogiyanto, 2015). After the elimination of TC5, TC8, TC9 and TEC 5 and 6 indicators, the model has fulfilled the convergent validity (Table 2 ).

Discriminant validity is assessed based on cross loading of construct measurements, which loading of indicators are higher on the construct than the other constructed loading (Jogiyanto \& Abdillah, 2009). Table 3 shows that the model has sufficient discriminant validity.
In addition, reliability test also found that all constructs are reliable with the criterion of reliability test value $>0.7$ (Table 2 ).

\section{Structural Model Results}

Hypothesis testing in this study using inner model with $95 \%$ confidence level and error analysis $(\alpha)=5 \%$. The test was performed using bootstrapping method in SmartPLS 3.2.7 software to obtain path coefficients $(\beta)$. To analyze the correlation between each variable and hypotheses research, the research is done by looking at the original sample value and comparing the $t$-statistic value with the $t$-table value. The criterion used is if $t$-statistic value is bigger than $\mathrm{t}$-table (1.64) with p-value $<0,05$ hence hypothesis accepted meaning significant influence between tested variables. Conversely, if the $\mathrm{t}$ statistic value is lower than t-table (1.64) and p-value $\geq 0.05$ then the hypothesis is rejected which means no effect between the variables tested.

Furthermore, to see the predictive nature of the independent variables to the dependent variable whether in the positive category can be assessed by looking at the original sample score. If the original sample is positive, the predictive value of the independent variable to the dependent variable is positive, whereas if the original sample is negative, it indicates that the prediction of the independent variable to the dependent variable is negative.

The result from bootstrapping method using SmartPLS version 3.2.7 which shows the coefficient for each hypothetical path in the re- 
Tabel 3. Cross Loading Results

\begin{tabular}{|c|c|c|c|c|c|}
\hline Ind/Var & Perf. & TC & TEC & TTF & UT \\
\hline Perf1 & 0.756668 & 0.250753 & 0.148843 & 0.170760 & 0.311566 \\
\hline Perf2 & 0.890469 & 0.305596 & 0.414241 & 0.320299 & 0.295790 \\
\hline Perf3 & 0.774832 & 0.121826 & 0.210800 & 0.412577 & 0.374641 \\
\hline Perf4 & 0.908609 & 0.339173 & 0.422546 & 0.310388 & 0.351648 \\
\hline Perf5 & 0.691138 & 0.258096 & 0.152053 & 0.374763 & 0.475754 \\
\hline Perf6 & 0.822485 & 0.317260 & 0.302409 & 0.346789 & 0.454780 \\
\hline $\mathrm{TC} 1$ & 0.223868 & 0.685363 & 0.318158 & 0.242604 & 0.316326 \\
\hline TC10 & 0.205013 & 0.752660 & 0.215916 & 0.172982 & 0.403271 \\
\hline TC2 & 0.306606 & 0.839232 & 0.315876 & 0.214336 & 0.369887 \\
\hline TC3 & 0.296774 & 0.791962 & 0.393809 & 0.278771 & 0.427518 \\
\hline $\mathrm{TC} 4$ & 0.175641 & 0.688874 & 0.371809 & 0.290230 & 0.445842 \\
\hline TC6 & 0.306618 & 0.838929 & 0.279421 & 0.212971 & 0.367095 \\
\hline TC7 & 0.255004 & 0.809738 & 0.211377 & 0.132444 & 0.235895 \\
\hline TEC1 & 0.238763 & 0.231915 & 0.568184 & 0.163328 & 0.130493 \\
\hline TEC10 & 0.280215 & 0.161705 & 0.565299 & 0.177954 & 0.124607 \\
\hline TEC11 & 0.328266 & 0.370395 & 0.622556 & 0.419742 & 0.293172 \\
\hline TEC12 & 0.366619 & 0.278490 & 0.789479 & 0.230334 & 0.297091 \\
\hline TEC13 & 0.165789 & 0.197457 & 0.570895 & 0.169321 & 0.068624 \\
\hline TEC14 & 0.443257 & 0.314033 & 0.758301 & 0.258320 & 0.267521 \\
\hline TEC2 & 0.126279 & 0.315197 & 0.839754 & 0.404121 & 0.327265 \\
\hline TEC3 & 0.205948 & 0.346148 & 0.823590 & 0.434597 & 0.232785 \\
\hline TEC4 & 0.121848 & 0.346160 & 0.856561 & 0.392722 & 0.264629 \\
\hline TEC7 & 0.181376 & 0.312222 & 0.671401 & 0.260064 & 0.272007 \\
\hline TEC8 & 0.219244 & 0.206671 & 0.558308 & 0.155753 & 0.060900 \\
\hline TEC9 & 0.376759 & 0.266965 & 0.761701 & 0.243880 & 0.302866 \\
\hline TTF1 & 0.377032 & 0.178088 & 0.404152 & 0.741654 & 0.179661 \\
\hline TTF10 & 0.245588 & 0.264238 & 0.449209 & 0.732885 & 0.347893 \\
\hline TTF11 & 0.360517 & 0.314423 & 0.314724 & 0.756669 & 0.362675 \\
\hline TTF12 & 0.353449 & 0.365798 & 0.401133 & 0.774204 & 0.539675 \\
\hline TTF13 & 0.379789 & 0.333870 & 0.364564 & 0.765080 & 0.514314 \\
\hline TTF14 & 0.237535 & 0.218398 & 0.350549 & 0.716955 & 0.392089 \\
\hline TTF15 & 0.163221 & 0.116165 & 0.203719 & 0.749237 & 0.349367 \\
\hline TTF16 & 0.585504 & 0.357084 & 0.353650 & 0.759197 & 0.624146 \\
\hline TTF17 & 0.333097 & 0.274648 & 0.202121 & 0.712459 & 0.360817 \\
\hline TTF18 & 0.208777 & 0.086637 & 0.388160 & 0.728915 & 0.138607 \\
\hline TTF19 & 0.269206 & 0.171163 & 0.217450 & 0.699347 & 0.422775 \\
\hline TTF2 & 0.363121 & 0.129946 & 0.375854 & 0.724564 & 0.310702 \\
\hline TTF20 & 0.057185 & 0.064302 & 0.341521 & 0.592594 & 0.023870 \\
\hline TTF3 & 0.339788 & 0.155176 & 0.374536 & 0.760848 & 0.329592 \\
\hline TTF4 & 0.168058 & 0.193362 & 0.168014 & 0.709828 & 0.313231 \\
\hline
\end{tabular}


Jurnal Dinamika Manajemen, 9 (1) 2018, 56-68

\begin{tabular}{llllll} 
TTF5 & 0.251640 & 0.113362 & 0.218502 & 0.779818 & 0.240647 \\
TTF6 & 0.261832 & 0.311349 & 0.259614 & 0.840670 & 0.466421 \\
TTF7 & 0.254140 & 0.185792 & 0.286569 & 0.732461 & 0.221871 \\
TTF8 & 0.119080 & 0.110144 & 0.263507 & 0.730062 & 0.214399 \\
TTF9 & 0.187687 & -0.073463 & 0.243017 & 0.602009 & 0.030385 \\
UT1 & 0.423969 & 0.484710 & 0.288057 & 0.482533 & 0.970895 \\
UT2 & 0.444948 & 0.448351 & 0.273632 & 0.460217 & 0.976474 \\
UT3 & 0.522985 & 0.490565 & 0.397585 & 0.479503 & 0.942941 \\
\hline
\end{tabular}

search model is presented in Table 4. Based on the results of hypothesis testing by bootstrapping method can be concluded that all hypothesis accepted statistically.

The result of hypothesis testing in structural model of PLS shows that task characteristics have an effect on conformity of technological tasks. This is in line with previous studies that indicate the characteristic connectivity of tasks and task-suitability of the technology (Goodhue, 1995; Maulina, 2015), the same is indicated in the context of the use of SIMDA Finance version 2.7 application in Local Government in Indonesia.

Conceptually, the task is the action undertaken by the individual in transforming the input into output, while the task characteristic is the nature of the task that includes responsibility, the kinds of tasks and the level of satisfaction derived from the work itself (Staples \& Seddon, 2004). Characteristics of the task can also be measured through five main characters, namely variety skills, task identity, autonomy, and feedback (Hackman \& Oldham, 1975). In the context of the use of SIMDA Finance version 2.7, the characteristics of the tasks performed by the user also contains aspects of task characteristics, such as variation, identity, and feedback. Any successful task will affect other colleagues to complete their tasks. In addition, SIMDA also authorizes and initiative to users to make decisions independently, especially related to the technical operation of SIMDA Finance.

The effect of task characteristics on the TTF in the context of the use of financial SIMDA can be explained by the mandatory nature of the SIMDA implementation so that the user is obliged to continue using this system with or without assessing the characteristics of the work task performed. In addition, SIMDA is an application that adopts the standard rules referring to Government Regulation No. 71 of 2010 on

Table 4. Structural Model Results

\begin{tabular}{lccccc}
\hline Var. & $\begin{array}{c}\text { Original } \\
\text { Sample }(\mathbf{O})\end{array}$ & $\begin{array}{c}\text { Sample } \\
\text { Mean }(\mathbf{M})\end{array}$ & $\begin{array}{c}\text { Standard Devia- } \\
\text { tion }(\text { STDEV })\end{array}$ & $\begin{array}{c}\text { Standard Error } \\
(\text { STERR })\end{array}$ & $\begin{array}{c}\text { T Statistics } \\
(\mathbf{O} / \text { STERR })\end{array}$ \\
\hline TC -> Perf & 0.063158 & 0.064649 & 0.019337 & 0.019337 & 3.266127 \\
TC -> TTF & 0.151787 & 0.154109 & 0.044241 & 0.044241 & 3.430921 \\
TC -> UT & 0.074775 & 0.077056 & 0.023393 & 0.023393 & 3.196487 \\
TEC -> Perf & 0.153660 & 0.156059 & 0.017895 & 0.017895 & 8.586846 \\
TEC -> TTF & 0.369291 & 0.372783 & 0.037093 & 0.037093 & 9.955733 \\
TEC -> UT & 0.181925 & 0.185454 & 0.019265 & 0.019265 & 9.443355 \\
TTF -> Perf & 0.416095 & 0.419110 & 0.030179 & 0.030179 & 13.787735 \\
TTF -> UT & 0.492633 & 0.498073 & 0.028461 & 0.028461 & 17.308839 \\
UT -> Perf & 0.368443 & 0.364465 & 0.034319 & 0.034319 & 10.735877 \\
\hline
\end{tabular}


Government Accounting Standards, as well as the Minister of Home Affairs Regulation No. 6 of 2013 on Implementation of Accrual Based Accounting Standards. The regulation directs the form of standardized task and technology characteristics so that the standard task characteristics can predict the suitability of tasks that are also standard.

This study also found the influence of technological characteristics on the suitability of technological tasks. These findings are in line with previous studies which indicate the better the technological characteristic implied in an SI, such as SIMDA Finance in the context of this study, the better the degree of suitability of the technology tasks used (Goodhue et al., 1995; Maulina, 2015).

There are several reasons why technological characteristics influence the technological task-suit in this study. First, the technology in this study refers to the application SIMDA Finance version 2.7 as a tool pengginderanya in completion of data processing tasks and financial reports. Technology is a tool used by individuals to help complete their tasks (Goodhue, 1995). Technology can be computer systems (both software and hardware, as well as data), and support services (training, and helpdesk) that provide assistance to technology users. Therefore, when the user is able to understand the meaning of the task well, then the user is also able to define the characteristics and properties of technology used.

Second, the basic characteristics of the technology used as benchmarks are able to provide information, user friendly, designed appropriately to facilitate access to information for users, reliable, fast innovation cycle, minimal response time, diverse technology, and stable (Maulina, 2015). In this research the majority of respondents perceive that the characteristics of technology from SIMDA Finance version 2.7 has met the basic characteristics of technology, which is able to present relevant information in the form of financial statements in accordance with regulations, display and design applications that are user friendly, quite reliable in pro- cessing data input, data in the form of a database that is encrypted so that when there is a problem or will use the data in the previous budget period can be easily to be restored, SIMDA Finance is also reinforced by the innovation and improvement of errors made by the developer by making application updates, quite responsive in usage, stable in various versions of windows operating system, and SIMDA finance has also adopted report format according to the accounting rule. Therefore, the fulfillment of technological characteristics in financial SIMDA has been able to influence the Task-Technology Adjustment.

In addition, this study also found a positive influence of TTF on utilization. These findings are in line with previous studies that indicate the more appropriate IT (eg SIMDA Finance technology) with tasks to be solved (eg creating financial reports for LGs), the higher the value of the benefits of IT applications (Goodhue et al., 1995; Darwin, 1999; Larsen et al., 2009). TTF is a determinant factor of belief about the usefulness, importance of use, and benefits derived from using IT (D'Ambra et al., 2013).

Sophisticated technology can not always improve productivity and IT must have conformity in helping individuals complete their tasks (Lin \& Huang, 2008; Zhou et al., 2010). In other words, although technology can be considered as something advanced or sophisticated, but if it does not fit the user's duties then the benefits of that technology will decrease. This also applies to mandatory applications, such as SIMDA Finance 2.7. Although the use of SIMDA Finance is a necessity, but psychological factors, such as user perceptions about IT conformity with tasks can lead to the use of IT is not optimal. Technology with functionality that aligns with the demands that exist in the task, as well as individual capabilities will help to complete tasks more quickly, more effectively, and more accurately. Thus, it can be concluded that the utilization can be used as a measurement of performance improvement, ie the better suitability of technology tasks SIMDA Finance version 2.7 
which is applied by the Local Government in Indonesia will further increase the intensity of the application utilization by users.

Furthermore, this study found that technology suitability variables positively affect the performance impact variables. This finding is in line with previous studies which indicate that the higher the suitability of task-technology will be the higher the impact of performance generated by its users (Goodhue et al., 1995; Maulina, 2015).

Technology according to the user "in accordance" with the demands that exist in the task and ability himself will lead to hope in the form of value or benefit value which will further encourage the user to utilize the technology. Indeed, the use of technology is also influenced by factors other than technological task conformity factors (such as social norms or situational factors), but at a certain level of utilization greater than zero, technologies containing high tech task conformance factors will lead to performance better because it can better meet the needs of user tasks. Thus, the conformance factor of the technology task and its utilization will positively affect the individual performance of the user of the technology. In this study, the size of the impact of enhanced individual performance is a combined implication of increased efficiency, effectiveness, and productivity in using IT that are influenced by various factors such as technological tasks, as well as the degree of utilization of IT used.

Regarding to the utilization of SIMDA Finance version 2.7 used in the local government environment in Indonesia, the results of the research indicate that the utilization has been very widely applied by the main financial manager in inputting financial data and making reports of transactions involving financial data in each Organization of Regional Devices. This happens because in addition to SIMDA Finance function that is in accordance with the needs of its users in assisting the job is also a boost of leadership in each OPD to continue to use this application as a main tool in processing financial data. In fact, the results show that SIMDA version 2.7 used today according to the user's perception is in accordance with the needs in carrying out its function as a tool in processing financial data so that users feel comfortable and confident of the work done. Thus, SIMDA can encourage users to work more optimally in realizing the effectiveness, productivity and quality of work is good.

The findings in this study support the TPC model showing TTF affecting the impact of individual performance. This finding is in line with previous studies that found the same thing (McGill \& Klobas, 2009; D'Ambra et al., 2013). In addition, the findings of this study are also in line with previous studies that found a stronger direct effect of technological characteristics on performance, rather than the effect of task characteristics. This confirms the importance of technological aspects of task-suitability as managerial aspects in the development and use of SIMDA within the Local Government in Indonesia, rather than technological aspects (technological characteristics).

In addition, this study also found a positive effect of utilization on the impact of performance. These findings are in line with previous studies which indicate that the higher the utilization of IT the higher the performance impacts generated by users (McGill \& Klobas, 2009; D'Ambra et al., 2013), the same is also indicated in the use SIMDA Finance version 2.7 in Local Government environment in Indonesia.

Finally, this study also found a positive effect of utilization on the impact of performance. These findings are in line with previous studies which indicate that the higher the utilization of IT the higher the performance impacts generated by users (McGill \& Klobas, 2009; D’Ambra et al., 2013), the same is also indicated in the use SIMDA Finance version 2.7 in Local Government environment in Indonesia. The findings of this research in addition to supporting the TPC model also support the DeLone and McClean Information Systems Success Model (2003) which identifies the SI success model as an antecedent to the performance impact that emphasizes the relationship between the use of 
IS by individuals on the impact of organizational performance. High quality of IS will affect the user's attitude to complete the tasks using the IS more easily and faster, so that the performance impact of productivity and efficiency will increase. Thus, the utilization of SIMDA financial version 2.7 has a role in supporting the performance of its users. It also indicates that the higher utilization of SIMDA Finance application in local government in Indonesia, the higher the performance impact it will produce.

\section{CONCLUSIONAND RECOMMENDATION}

This study examines the TPC model in the context of the implementation of SIMDA Finance in the local government environment in Indonesia. Theoretically, this study finds the ability of the TPC model to explain the use of SI in the context of public sector organizations, especially government agencies. Thus, the TPC model can be developed in the context of nonprofit organizations out of context when the TPC model was developed and tested in many previous studies. Thus, the theoretical contributions presented by this study of TPC model development in the context of government institutions, particularly the relatively limited local government in Indonesia, were studied in previous studies.

Practically, this study finds the importance of TTF factors in predicting the use of SIMDA Finance 2.7 and performance impacts in Local Government Environments in Indonesia. These findings indicate the need for the stakeholders of SIMDA Finance 2.7 to maintain and ensure the development of SIMDA Finance applications meet the aspects of task characteristics and the relevant technological characteristics in the context of business processes of local government agencies.

Methodologically, this study also has limitations that anticipated by similar studies in the future, the relatively low questionnaire response rate. For that, future studies need to seek out tips on increasing the response rate to improve the region's generalization of sample gene- ralizations to the population. In addition, this study uses a variance-based SEM-PLS technique that focuses on construct-construct predictions, so the study has not been fully able to test the suitability of the model with the research context. For that, future studies can develop and test similar models using Covarian-based SEM techniques.

\section{REFERENCES}

Asrori. 2011. Penggunaan Sistem Informasi Penilaian Kinerja Dosen dan Akuntabilitas Kinerja Dosen. Jurnal Dinamika Manajemen. 2 (2): 162-168.

Aljukhadar, M., Senecal, S \& Nantel, J. 2014. Is More Always Better? Investigating the TaskTechnology Fit Theory in an Online User Context. Information and Management. 51 (2): 391-397.

Baroudi, J. J., Olson, M. H \& Ives, D. 1986. An Empirical Study of the Impact of User Involvement on System Usage and Information Satisfaction. Communications of the ACM. 29 (3): 232-238.

Barratt, M. 2004. Understanding the Meaning of Collaboration in the Supply Chain. Supply Chain Management. 9 (1): 30-42.

Chang, H. H., Tsai, Y. C \& Hsu, C. H. 2013. E-procurement and Supply Chain Performance. Supply Chain Management. 18 (1): 34-51.

D’Ambra, J \& Wilson, C. S. 2004. Explaining Perceived Performance of the World Wideweb: Uncertainty and the Task-Technology Fit Model. Internet Research Volume. 14 (4): 294-310.

D’Ambra, J., Wilson, C. S \& Akter, S. 2013. Application of the Task-Technology Fit Modelto Structure and Evaluate the Adoption of EBooks by Academics. Journal of the American Society for Information Science and Technology. 64 (1): 48-64.

Delone, W. H \& McLean, E. R. 2003. The DeLone and McLean Model of Information Systems Success: a Ten-Year Update. Journal of Management Information Systems. 19 (4):9-30.

Goodhue, D. L \& Thompson, R. L. 1995. TaskTechnology Fit and Individual Performance. MIS Quarterly. 19(2): 213-236. 
Goodhue, D. L. 1998. Development and Measurement Validity of Task-Technology Fit Instrument for User Evaluations of Information System. Decision Sciences. 29 (1): 105-138.

Hackman, J. R \& Oldham, G. R. 1975. Development of the Job Diagnostic Survey. Journal of Applied Psychology. 60 (2): 159-170.

Hartwick, J \& Barki, H. 1994. Explaining the Role of User Participation in Information System Use. Management Science. 40 (4): 440-465.

Huo, B., Ye, Y., Zhao, X \& Shou, Y. 2016. The Impact of Human Capital on Supply Chain Integration and Competitive Performance. International Journal of Production Economics. 178: 132-143.

Igbaria, M., Parasuraman, S \& Badaway, M. K. 1994. Work Experience, Job Involvement, and Quality of Work Life Among Information Systems Personnel. MIS Quarterly:175-201.

Jogiyanto, H. M. 2007. SI Keperilakuan. Yogyakarta: Andi Offset

Jogiyanto, H. M \& Abdillah, W. 2009. Konsep dan Aplikasi PLS (Partial Least Square) Untuk Penelitian Empiris. Yogyakarta: BPFE UGM.

Larsen, T. J., Sørebø, A. M \& Sørebø, Ø. 2009. The Role of Task-Technology Fit as Users' Motivation to Continue Information System Use. Computers in Human Behavior. 25 (3): 778-784.

Liao, S. H., Hu, D. C \& Ding, L. W. 2017. Assessing the Influence of Supply Chain Collaboration Value Innovation, Supply Chain Capability and Competitive Advantage in Taiwan's Networking Communication Industry. International Journal of Production Economics. 191: 143-153.

Lin, T. C \& Huang, C. C. 2008. Understanding Knowledge Management System Usage Antecedents: an Integration of Social Cognitive Theory and Task Technology Fit. Information and Management. 45 (6): 410-417.

Lu, H. P \& Yang, Y. W. 2014. Toward an Understanding of the Behavioral Intention to Use a Social Networking Site: Anextensionof Task-Technology Fit Tosocial-Technology Fit. Computers in Human Behavior. 34: 323332.

McGill, T.J \& Klobas, J. E. 2009. A Task-Technolo- gy Fit View of Learning Management System Impact. Computers and Education. 52 (2): 496-508.

Montazemi, A. R., Cameron, D. A \& Gupta, K. M. 1996. An Empirical Study of Factors Affecting Software Package Selection. Journal of Management Information System. 13 (1): 89105.

Maulina, C. 2015. Pengaruh Karakteristik Tugas, TI dan Individu terhadap Task-Techonolgy Fit (TTF), Utilisasi dan Kinerja. Jurnal Ilmu Sosial dan Ilmu Politik. 4 (1).

Oliveira, T., Faria, M., Thomas, M. A \& Popovic, A. 2014. Extending the Understanding Ofmobile Banking Adoption: When UTAUT Meets TTF and ITM. International Journal of Information Management. 34 (5): 689-703.

Parkes, A. 2013. The Effect of Task-IndividualTechnology Fit on User Attitude and Performance: an Experimental Investigation. Decision Support Systems. 54 (2): 997-1009.

Puschmann, T \& Alt, R. 2005. Successful Use of EProcurement in Supply Chains. Supply Chain Management. 10 (2): 122-133.

Sundram, V. P. K., Chandran, V. G. R \& Bhatti, M. A. 2016. Supply Chain Practices and Performance: the Indirect Effects of Supply Chain Integration. Benchmarking. 23 (6): 14451471.

Staples, D. S \& Seddon. 2004. Testing the Technology-to-Performance Chain Model. Journal of Organizational and End User Computing. 16 (4): $17-35$

Stettheimer, T. D \& Ana D. C. 1998. Modeling Utilization of Planned Information Technology. American Medical Informatics Association: 290-294.

Susanti, V. A. 2006. Teknologi Tugas yang Fit dan Kinerja Individual. Jurnal Akuntansi dan Keuangan. 8 (1): 24-34.

Zaman, K. A. U \& Ahsan, A. M. M. N. 2014. Lean Supply Chain Performance Measurement. International Journal of Productivity and Performance Management. 63 (5): 588-612.

Zhou, T., Lu, Y \& Wang, B. 2010. Integrating TTF and UTAUT to Explain Mobile Bankinguser Adoption. Computers in Human Behavior. 26 (4): 760-767. 